\title{
Development and Evaluation of Nevirapine Extended Release Tablets using QbD Approach
}

\author{
Vasantakumar Pai Karkala1, Harsha Jinadatharaya', Devagowda Vishakante Gowda',", Praveen \\ Sivadasu ${ }^{2}$
}

1'Department of Industrial Chemistry, Kuvempu University Shankaraghatta, B. R. Project, Shimoga-577451, Karnataka, INDIA. ${ }^{2}$ Department of Pharmaceutics, JSS Academy for Higher Education and Research, JSS College of Pharmacy, SS Nagara, Mysore -570015 , Karnataka, INDIA.

\begin{abstract}
Objective: To develop and evaluate Nevirapine (NVP) Extended release tablets for reducing the dosing frequency using Methylcellulose USP Methocel A15-LV and Hypromellose USP Methocel K4M Premium CR used as rate retarding polymers and Magnesium stearate as lubricant. Methods: Tablets were prepared by using roller compaction technique by employing Quality by Design $(\mathrm{ObD})$ and Design of Experimentation (DoE) to study the effect of various process related parameters like Bulk density, Tapped density, Compressibility index, mesh size and in-vitro release data at 20th hour. Results: Obtained results had suggested that concentration of polymer had shown a potential effect over various process parameters and in-vitro drug release studies suggested that formulated tablets had shown a sustained release up to $24 \mathrm{~h}$ when compared with marketed formulations. Conclusion: From the obtained results it can be concluded that formulation of Nevirapine ER Tablets employing $\mathrm{QbD}$ lead to a single dose per day in the management of HIV/AIDS.
\end{abstract}

Key words: Quality by design, Nevirapine, Design of experimentation, Extended release, HIV/AIDS, Tablets.

\section{INTRODUCTION}

The basic concept of employing QbD approach in preparing any formulation is "Quality cannot be tested but should be built into it". ${ }^{1}$ As per ICH, QbD can be defined as a systematic approach to develop a formulation with predefined objectives and special highlighting on process designing and quality risk management. ${ }^{2}$ One of the major parameter in $\mathrm{QbD}$ is developing a design which includes, Equipment, excipients and manufacturing environments, any design space should get prior approval from regulatory bodies. In this design space various product variables are monitored in periodic manner for better quality of product. All these parameters will be assessed and conclusions will be reported. ${ }^{3}$ Studies suggested that by employing QbD approach large scale productivity of the formulation can be improved, so that they can be released into the market. ${ }^{4}$

Controlled or extended release is a system which provides a continuous release of the medicament for a pre-determined time interval. This infers that release of the medicament from a controlled system proceeds at a rate which is not only predictable but also reproducible. $^{5}$ Administration of these systems through oral route will be considered based on the disease, patient, duration of therapy and properties of the drug. Extended release systems controls the delivery of the medicament temporarily, it also makes an attempt to deliver the drug constantly at the deliver site. ${ }^{6}$ It was reported that by formulating this controlled release systems the polymers obtained enhanced chain mobility and increased free macromolecular chains
Submission Date: 15-02-2018; Revision Date: 17-05-2018; Accepted Date: 14-08-2018

DOI: 10.5530/ijper.52.4s.101 Correspondence:

Dr. Devagowda Vishakante Gowda,

Professor and Head, Department of Pharmaceutics, JSS Academy of Higher Education and Research, Mysore-15, Karnataka, INDIA.

Phone: +91 9663162455 E-mail:dvgowdajssuni@ gmail.com

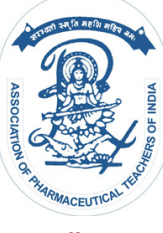

www.ijper.org 
to diffuse through oral mucus layers and sustaining the release of drug from the formulation. ${ }^{7}$

Nevirapine (NVP) is a Non-nucleoside reverse transcriptase inhibitor (NNRTI) of human immune deficiency virus Type-1, which terminates the polymerase activity by getting attached to HIV-1 reverse transcriptase which results in disturbance of enzyme's catalytic site. In recent years research works demonstrated that NVP has shown prominent activity in HIV infected patients in combination of other drugs in therapy. NNRTI's acts by binding and blocking HIV reverse transcriptase and avoids HIV from replicating and resulting in the amount of HIV in blood. NVP reduces the risk of transmitting HIV to non-infected people as it binds to Reverse transcriptase (RT) and blocks RNA and DNA dependent polymerase activities by creating disturbances at enzymes catalytic site. ${ }^{8}$ It was reported that in spite of its benefits treatment with NVP can cause severe hepatotoxicity and rashes. Studies suggested that NVP undergoes hepatic metabolism by cytochrome p450 and transformed into several hydroxylated metabolites and these metabolites are responsible to adverse effects when compared with parent molecule. ${ }^{9-10}$ The objective of present research was to develop an extended release tablet loaded with NVP employing QbD approach to reduce the dosing frequency and adverse effects caused by the metabolites in managing HIV/AIDS.

\section{MATERIALS AND METHODS}

\section{Materials}

Nevirapine was obtained as a gift sample from Apotex Research Pvt Ltd, Bengaluru. The other chemicals and excipients used in the study were of analytical grade.

\section{Methods}

\section{Quality Target Product Profile for Nevirapine ER Tablets}

In combination with other antiretroviral agents Nevirapine ER Tablets are indicated as an alternative for treatment of HIV-1 infection. A brief explanation about quality characteristics that affects formulation of Nevirapine ER Tablets is given in Table 1.

\begin{tabular}{|c|c|c|c|}
\hline \multicolumn{2}{|c|}{ QTPP Element } & Target & Justification \\
\hline \multicolumn{2}{|c|}{ Dosage form } & Tablet & $\begin{array}{l}\text { ANDA needs same dosage form as that of } \\
\text { Reference product }\end{array}$ \\
\hline \multicolumn{2}{|c|}{ Dosage design } & Extended release tablet & $\begin{array}{l}\text { Extended Release design } \\
\text { Needed to meet label claim. }\end{array}$ \\
\hline \multicolumn{2}{|c|}{ Route of Administration } & Oral & Required to match the Reference product \\
\hline \multicolumn{2}{|c|}{ Dosage strength } & $\begin{array}{l}\text { Nevirapine ER Tablets } \\
\qquad 400 \mathrm{mg}\end{array}$ & $\begin{array}{l}\text { Pharmaceutical equivalence } \\
\text { requirement: Same strength as that of the } \\
\text { Reference product }\end{array}$ \\
\hline \multicolumn{2}{|c|}{ Container closure system } & HDPE bottles with Caps & Needed for safety and commercial requirements \\
\hline \multicolumn{2}{|c|}{ Pharmacokinetics } & $\begin{array}{l}\text { Extended release Bioequivalent (BE) } \\
\text { to Reference Product. }\end{array}$ & $\begin{array}{c}\text { Maximum plasma concentration } \\
\text { (Cmax) and the area under the curve (AUC) are } \\
\text { bioequivalence requirements. Tmax ensures rapid } \\
\text { onset of action. Bioequivalence requirement. } \\
\text { Needed to ensure rapid onset and efficacy. }\end{array}$ \\
\hline \multirow{8}{*}{$\begin{array}{l}\text { Drug Product } \\
\text { quality } \\
\text { attributes }\end{array}$} & Physical attributes & \multirow{8}{*}{\multicolumn{2}{|c|}{$\begin{array}{l}\text { Pharmaceutical equivalence requirement: Meeting the same or Compendial or other } \\
\text { applicable (quality) standards (i.e., identity, assay, purity, and quality). }\end{array}$}} \\
\hline & Identification & & \\
\hline & Assay & & \\
\hline & Content uniformity (CU) & & \\
\hline & $\begin{array}{l}\text { Degradation products / } \\
\text { Impurities }\end{array}$ & & \\
\hline & Residual solvents & & \\
\hline & Dissolution & & \\
\hline & Microbial Limits & & \\
\hline \multicolumn{2}{|c|}{ Patient compliance to the product } & $\begin{array}{l}\text { Organoleptic properties - } \\
\text { shape, size and colour }\end{array}$ & $\begin{array}{l}\text { Shape, size and colour similar } \\
\text { to the reference product for patient acceptability }\end{array}$ \\
\hline \multicolumn{2}{|r|}{ Stability } & $\begin{array}{l}\text { At least 24-month shelf-life at room } \\
\text { temperature. }\end{array}$ & Needed for commercialization \\
\hline
\end{tabular}


Identification of critical and non-critical quality attributes (CQAs) for Nevirapine ER Tablets

CQA's were established based on the QTPP's defined in the above table for the development of Nevirapine Extended-Release Tablets. The attributes which have a potential effect on formulation variables during development of process which are related to the safety of the product formulated are termed as CQA. A brief explanation about CQA's are depicted in Table 2.

\section{CMAs of Excipient}

The critical material attributes of all the excipients which have impact on the final formulation are listed and discussed below in Table 3.

\begin{tabular}{|c|c|c|c|c|}
\hline \multicolumn{2}{|c|}{$\begin{array}{l}\text { Drug Product quality } \\
\text { attributes }\end{array}$} & Target & $\begin{array}{l}\text { Is this } \\
\text { Critical? }\end{array}$ & $\begin{array}{l}\text { Justification of } \\
\text { criticality }\end{array}$ \\
\hline \multirow{4}{*}{$\begin{array}{l}\text { Physical } \\
\text { attributes }\end{array}$} & $\begin{array}{l}\text { Appearance } \\
\text { (Colour) }\end{array}$ & $\begin{array}{l}\text { Colour suggested } \\
\text { by marketing group }\end{array}$ & Yes & $\begin{array}{l}\text { Pharmaceutical requirement, process and stability may } \\
\text { have an impact on appearance }\end{array}$ \\
\hline & Size & $\begin{array}{c}\text { Similar to } \\
\text { Reference Product }\end{array}$ & No & $\begin{array}{l}\text { Formulation impacts } \\
\text { size. }\end{array}$ \\
\hline & Score configuration & Unscored & No & Not critical because tablet is Unscored. \\
\hline & Friability & NMT $0.8 \% \mathrm{w} / \mathrm{w}$ & Yes & Both formulation and Process impact friability. \\
\hline \multicolumn{2}{|r|}{ Identification } & $\begin{array}{l}\text { Positive for } \\
\text { Nevirapine }\end{array}$ & No & $\begin{array}{l}\text { Both formulation and } \\
\text { Process unlikely to impact the identity. }\end{array}$ \\
\hline & Assay & $\begin{array}{l}90-110 \% \text { of label } \\
\text { claim }\end{array}$ & Yes & $\begin{array}{c}\text { Needed for clinical } \\
\text { Effectiveness and safety. Process variables may affect the } \\
\text { assay value of the Drug product. }\end{array}$ \\
\hline \multicolumn{2}{|c|}{$\begin{array}{l}\text { Content uniformity } \\
\text { (CU) }\end{array}$} & $\begin{array}{l}\text { Complies with } \\
\text { harmonized } \\
\text { requirements } \\
\text { for uniformity of } \\
\text { dosage units }\end{array}$ & Yes & $\begin{array}{l}\text { Needed for clinical effectiveness and both formulation and } \\
\text { process impact the uniformity }\end{array}$ \\
\hline \multicolumn{2}{|c|}{ Degradation products / Impurities } & $\begin{array}{c}\text { Each Individual } \\
\text { unidentified } \\
\text { impurity: NMT } \\
0.1 \% \text { Total } \\
\text { Impurities: NMT } \\
0.2 \% \\
\end{array}$ & Yes & As per $\mathrm{ICH}$ guideline and needed to ensure safety \\
\hline \multicolumn{2}{|r|}{ Dissolution } & $\begin{array}{l}\text { As per USP } \\
02 \mathrm{H}: \mathrm{NMT} 25 \% \\
08 \mathrm{H}: 50-70 \% \\
20 \mathrm{H}: \mathrm{NLT} 80 \%\end{array}$ & Yes & $\begin{array}{l}\text { Needed for clinical } \\
\text { Effectiveness and both formulation and process affect drug } \\
\text { release profile. }\end{array}$ \\
\hline \multicolumn{2}{|c|}{ Microbial Limits } & $\begin{array}{l}\text { Meet relevant } \\
\text { pharmacopoeia } \\
\text { criteria }\end{array}$ & No & $\begin{array}{l}\text { Formulation and process } \\
\text { Unlikely have any impact. }\end{array}$ \\
\hline
\end{tabular}

\begin{tabular}{|c|c|c|}
\hline Material Attribute & \multicolumn{2}{|c|}{ CMA } \\
\hline \multirow[t]{5}{*}{ Excipients Name and Functional use } & Excipients Name & Functional use \\
\hline & Hydroxypropyl méthyl cellulose premium & Release controlling polymer \\
\hline & Methyl cellulose & Diluent \\
\hline & Magnesium stearate & Lubricant \\
\hline & Iron Oxide & Colourant \\
\hline $\begin{array}{l}\text { Compendial } \\
\text { Requirements }\end{array}$ & \multicolumn{2}{|c|}{ Complies } \\
\hline Interaction with drug substance & \multicolumn{2}{|c|}{$\begin{array}{l}\text { The results of the study confirmed that when these excipients, representing different } \\
\text { functional uses in formulation, are combined with Nevirapine and were exposed to solid } \\
\text { state stress conditions, no significant difference in impurity levels and (\%) Assay was } \\
\text { observed. Hence above mentioned. }\end{array}$} \\
\hline
\end{tabular}


Manufacturing process of Nevirapine ER Tablets using DoE

\section{Experimental Design}

A $2^{3}$ 2-Level factorial design was employed to evaluate the existing curvature effects one centre point. Force, gap and speed of the roller compactor were considered as independent variables. Granule bulk density, tap density, Carr's index and Dissolution at $20 \mathrm{~h}$ were used as dependent variables. Best fit model for statistical analysis was considered significant when $P$ value was less than 0.05.

\section{Preparation of Nevirapine ER Tablets}

Based on the physico-chemical properties of NVP, roller compaction was selected as the most appropriate manufacturing process. In addition, the NVP physical properties (flow) suggested precluded direct compression as the method for formulating tablets. Hypromellose (Methocel K4M Premium) and Methylcellulose (Methocel A15-LV) were separately weighed, sieved and then mixed with NVP. The mixture was then lubricated by intragranular Magnesium stearate and roller compacted to yield active granules by milling the formed ribbon. Prior to compression one more step of lubrication was done by adding extra-granular (Magnesium stearate) and the mixture was forwarded to compression. Formulation chart for formulating NVP Tablets is shown in Table 4.

\section{Characterization of Granules}

\section{Bulk density}

Measurement of Bulk density was done by pouring powder into a measuring cylinder through sieve \# 20 and the initial weight was noted. The initial volume was termed as bulk volume. ${ }^{11}$

\section{Tapped density}

Tapped density is defined as the ratio between aggregate weights of granules to the tapped volume of powder. Measurement of the volume was done by tapping the granules 750 times. If the variance in volume exceeds $2 \%$, further tapping should be done for 1250 times. It was conveyed in $\mathrm{g} / \mathrm{ml} .^{12}$

\section{Angle of Repose}

Angle of repose was done by using powder flow tester. Angle of repose can be calculated by measuring the height and radius of the pile of granules..$^{13}$

\section{Compressibility index}

It demonstrates the flow properties of the granules. It is conveyed in the form of $\%$ and can be calculated using bulk density and tapped density. ${ }^{13}$

\begin{tabular}{|c|c|c|}
\hline \multicolumn{3}{|c|}{ Table 4: Composition of Nevirapine ER Tablets 400 mg. } \\
\begin{tabular}{|c|c|} 
SI. \\
No.
\end{tabular} & Ingredient & mg/ tablet \\
\cline { 3 - 3 } & NEVIXAG-081 \\
\hline 1. & Nevirapine Anhydrous USP* & 400.0 \\
\hline 2. & Methylcellulose USP Methocel A15-LV** & 82.5 \\
\hline 3. & Hypromellose USP Methocel K4M & 108.0 \\
\hline 4. & Premium CR & 2.0 \\
\hline 5. & Yellow Iron Oxide NF & 1.5 \\
\hline & Magnesium stearate (Intragranular) & 6.0 \\
\hline & Tablet weight & 600.0 \\
\hline
\end{tabular}

\section{Hausner Ratio}

Hausner ratio is an indirect way of accessing the ease of granules flow. It can be calculated by using bulk density and tapped density. ${ }^{13}$

\section{Evaluation of compressed Nevirapine ER Tablets $400 \mathrm{mg}$}

\section{Weight Variation}

Randomly 20 tablets were selected and weighed using a single balance. Standard deviations were calculated and checked with the standard pharmacopeial limits. ${ }^{14}$

\section{Thickness}

Tablets were selected randomly from all batches and measurement of thickness was done by using Vernier Calliper. ${ }^{14}$

\section{Hardness}

The strength of tablet is expressed in the form of tensile strength $\left(\mathrm{Kg} / \mathrm{cm}^{2}\right)$. The amount of force required to break the tablets was measured by using a hardness tester. ${ }^{15}$

\section{Friability}

Randomly 20 tablets were selected and weighed from all the batches. The weighed tablets then placed in friabilator and then ran for 100 revolutions. After completion of 100 revolutions tablets were de-dusted, re-weighed and $\%$ friability was calculated. ${ }^{16}$

\section{In vitro dissolution studies}

Dissolution studies for extended release of NVP from the formulated tablets were done by USP type-2 dissolution apparatus using $6.8 \mathrm{pH}$. Phosphate buffer at 75 $\mathrm{rpm}$ and $37 \pm 0.5^{\circ} \mathrm{C}$ for $24 \mathrm{~h}$. Quantity of drug dissolved in the selected buffer was estimated periodically by using ultra violet (UV) spectrophotometer (UV-1601 PC Shimadzu, Japan) at $244 \mathrm{~nm} .{ }^{17}$ 


\section{RESULTS AND DISCUSSION}

\section{Optimization of Nevirapine ER Tablets}

Optimization of Nevirapine ER Tablets was done by employing $2^{3} 2$-Level factorial design. Force, gap and speed of the roller compactor were considered as independent variables. Granule bulk density, tap density, Carr's index, Granule size distribution (retains on \#60 mesh ASTM) and Dissolution at $20 \mathrm{~h}$ were used as dependent variables, whereas levels $-1,0,+1$ were used as ranges of variables respectively which is depicted in Table 5 and 6.

\section{Experimental Design}

The summary of data obtained of various responses for Nevirapine ER Tablets is presented in Table 7.

\section{Summary of results of regression analysis for responses}

The summary of ANOVA analysis was given in Table $8 \mathrm{a}$ and $8 \mathrm{~b}$.

\section{Effect of formulation variables on Bulk density of granules}

As depicted in the Pareto chart (Figure 1a), the significant factors affecting Bulk density of granules was roll pressure and roll gap. The contour plot for roll gap and roll pressure versus Bulk density of granules presented in the (Figure 1b), showed that bulk density of granules increased with increasing roll pressure (positive effect) and decreases with increasing roller gap (Negative effect).

\section{Effect of formulation variables on Tap density of granules}

As depicted in the Pareto chart Figure 2a and Counter plot Figure $2 \mathrm{~b}$, no parameter had significant effect on the granules Tap density.

\begin{tabular}{|c|c|c|c|}
\hline \multicolumn{4}{|c|}{ Independent variable Levels } \\
\hline & Low & Medium & High \\
\hline A: Force $(\mathrm{KN} / \mathrm{cm})$ & 6 & 10 & 14 \\
\hline B:Gap (mm) & 2 & 3 & 4 \\
\hline C: Speed (rpm) & 2 & 3 & 4 \\
\hline
\end{tabular}

\begin{tabular}{|c|c|c|c|}
\hline \multicolumn{4}{|c|}{ Table 6: $\mathbf{2}^{\mathbf{3}}$ 2-Level factorial design layout for } \\
Nevirapine ER Tablets.
\end{tabular}

\section{Effect of formulation variables on Compressibility} Index of granules

As depicted in the Pareto chart Figure 3a, the formulation variables which had shown a significant effect on Carr's index of granules was pressure applied on roll and gap between the roll. The contour plot for roll gap and roll pressure versus Carr's index of granules presented in the Figure 3b, showed that Carr's index of granules decreased with increasing pressure on the roll which can be termed as Negative effect and increases with enancing

\begin{tabular}{|c|c|c|c|c|c|}
\hline \multicolumn{6}{|c|}{ Table 7: Observed response in $\mathbf{2}^{\mathbf{3}}$ 2-Level factorial design for Nevirapine ER Tablets. } \\
\hline Run & $\begin{array}{c}\text { Bulk density } \\
\text { (g/ml) }\end{array}$ & $\begin{array}{c}\text { Tapped density } \\
(\mathbf{g} / \mathbf{m l})\end{array}$ & $\begin{array}{c}\text { Compressibility Index } \\
(\%)\end{array}$ & $\begin{array}{c}\text { Granules PSD } \\
\text { Above \#60 mesh } \\
\text { (\%) }\end{array}$ & In vitro release at 20h \\
\hline 1 & 0.481 & 0.786 & 38.804 & 59.00 & 88 \\
\hline 2 & 0.520 & 0.782 & 33.504 & 47.60 & 89 \\
\hline 3 & 0.581 & 0.799 & 27.284 & 51.10 & 91 \\
\hline 4 & 0.540 & 0.793 & 31.904 & 64.80 & 99 \\
\hline 5 & 0.530 & 0.776 & 31.701 & 65.64 & 93 \\
\hline 6 & 0.547 & 0.771 & 29.053 & 63.02 & 89 \\
\hline 7 & 0.499 & 0.792 & 36.995 & 48.18 & 93 \\
\hline 8 & 0.572 & 0.787 & 27.319 & 51.48 & 89 \\
\hline 9 & 0.510 & 0781 & 34.669 & & 90 \\
\hline
\end{tabular}




\begin{tabular}{|c|c|c|c|c|c|c|}
\hline \multicolumn{9}{|c|}{ Table 8a: Summary of ANOVA analysis. } \\
\hline \multirow{2}{*}{ ANOVA Analysis } & \multicolumn{2}{|c|}{ Granule Bulk density } & \multicolumn{2}{c|}{ Granule Tapped Density } & \multicolumn{2}{c|}{$\begin{array}{c}\text { Granules Compressibility Index } \\
\text { (\%) }\end{array}$} \\
\cline { 2 - 7 } & p- values & SR & p- values & SR & p-values & SR \\
\hline Model & 0.001 & Yes & 0.4693 & No & 0.0046 & Yes \\
\hline Roller Force & 0.003 & Yes & 0.7291 & No & 0.0014 & Yes \\
\hline Roller Gap & 0.0043 & Yes & 0.7870 & No & 0.0185 & Yes \\
\hline Roller Speed & 0.2048 & No & 0.1659 & No & 0.9612 & No \\
\hline
\end{tabular}

\begin{tabular}{|c|c|c|c|c|}
\hline \multicolumn{4}{|c|}{ Table 8b: Summary of ANOVA analysis. } \\
\hline \multirow{2}{*}{ ANOVA Analysis } & $\begin{array}{c}\text { PSD \#60 mesh } \\
\text { Retained }\end{array}$ & \multicolumn{2}{c|}{ Dissolution at $20 \mathrm{~h}$} \\
\cline { 2 - 5 } & p- values & SR & p- values & SR \\
\hline Model & 0.0071 & Yes & 0.2760 & No \\
\hline Roller Force & 0.0017 & Yes & 0.4079 & No \\
\hline Roller Gap & 0.1981 & No & 0.3125 & No \\
\hline Roller Speed & 0.2911 & No & 0.1384 & No \\
\hline
\end{tabular}
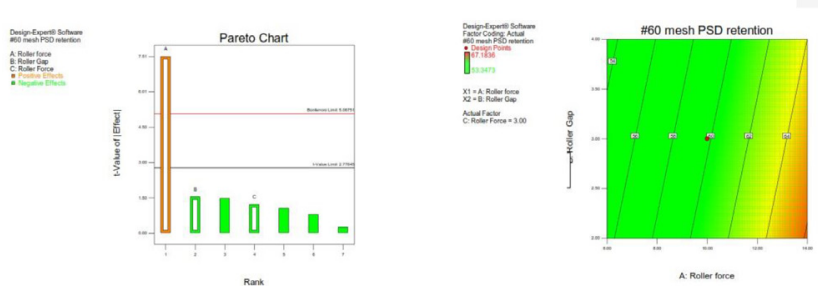

Figure 4a and 4b: Pareto chart and counterplot for Effect of PSD on granules.

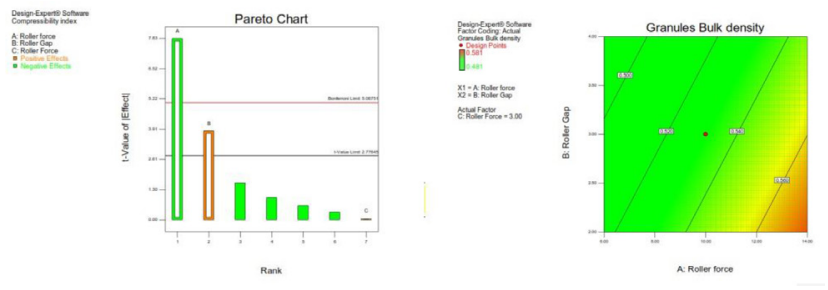

Figure 1a and 1b: Pareto chart and counterplot for Effect of Bulk Density of Granules.

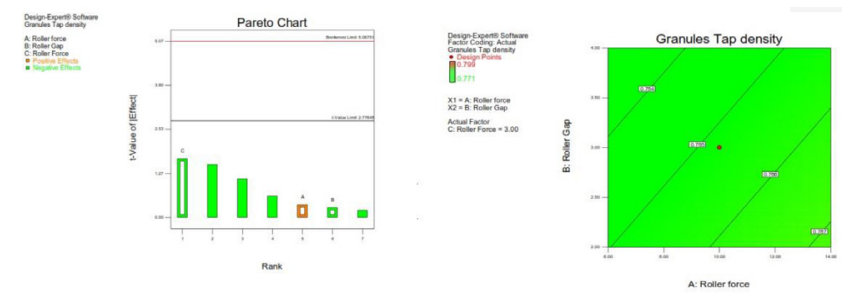

Figure 2a and 2b: Pareto chart and counterplot for Effect of Granules Tap Density.
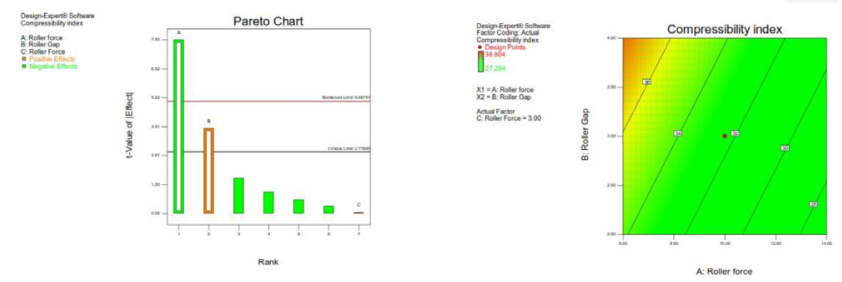

Figure 3a and 3b: Pareto chart and counterplot for Effect of Compressibility index.
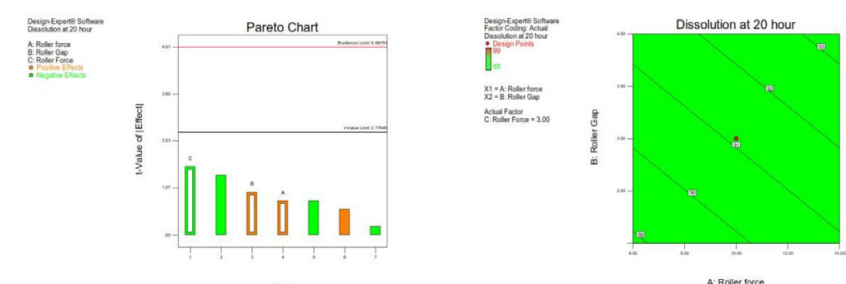

Figure 5a and 5b: Pareto chart and counterplot for Effect of dissolution at $20 \mathrm{~h}$.

the gap between roll which can be termed as Positive effect.

\section{Effect of formulation variables on granules PSD Above \#60 ASTM mesh}

As depicted in the Pareto chart Figure 4a, the important formulation variables afecting PSD Above \#60 ASTM mesh was Roller force. The contour plot for PSD Above \#60 ASTM mesh versus roll force and roll gap versus is presented in the Figure 4b, showed that. PSD Above \#60 ASTM mesh increased with increasing roll force (positive effect).

\section{Effect of formulation variables on Tablet dissolution at $20 \mathrm{H}$}

Dissolution is one of CQAs of the drug product. Roller compaction process may affect the dissolution of the drug product. But form the Pareto chart and counterplot Figure $5 \mathrm{a}$ and $5 \mathrm{~b}$; it can be observed that, no parameter 


\section{Table 9: Characterization of Granules.}

\begin{tabular}{|c|c|c|c|c|c|}
\hline $\begin{array}{c}\text { SI. } \\
\text { No }\end{array}$ & $\begin{array}{c}\text { Bulk } \\
\text { density }\end{array}$ & $\begin{array}{c}\text { Tapped } \\
\text { density }\end{array}$ & $\begin{array}{c}\text { Angle of } \\
\text { repose }\end{array}$ & $\begin{array}{c}\text { Compressibility } \\
\text { index }\end{array}$ & $\begin{array}{c}\text { Hausner } \\
\text { ratio }\end{array}$ \\
\hline 1 & 0.481 & 0.786 & 29.18 & 38.804 & 1.63 \\
\hline 2 & 0.520 & 0.782 & 28.39 & 33.504 & 1.50 \\
\hline 3 & 0.581 & 0.799 & 26.54 & 27.284 & 1.37 \\
\hline 4 & 0.540 & 0.793 & 26.24 & 31.904 & 1.46 \\
\hline 5 & 0.530 & 0.776 & 27.14 & 31.701 & 1.46 \\
\hline 6 & 0.547 & 0.771 & 27.88 & 29.053 & 1.40 \\
\hline 7 & 0.499 & 0.792 & 28.65 & 36.995 & 1.58 \\
\hline 8 & 0.572 & 0.787 & 26.89 & 27.319 & 1.37 \\
\hline 9 & 0.510 & 0781 & 29.85 & 34.669 & 1.53 \\
\hline
\end{tabular}

\begin{tabular}{|c|c|c|c|c|}
\hline SI. No & Weight (mg) & $\begin{array}{l}\text { Thickness } \\
\text { (mm) }\end{array}$ & $\begin{array}{c}\text { Hardness } \\
\left(\mathbf{k g} / \mathrm{cm}^{2}\right)\end{array}$ & $\begin{array}{c}\text { Friability } \\
\text { (\%) }\end{array}$ \\
\hline 1 & $596-608$ & $6.09-6.23$ & $12.4-16.4$ & 0.094 \\
\hline 2 & $586-615$ & $6.15-6.28$ & $11.4-15.3$ & 0.03 \\
\hline 3 & $595-607$ & $6.09-6.18$ & $14.2-15.5$ & 0.015 \\
\hline 4 & $595-612$ & $6.19-6.30$ & 11.6-14.1 & 0.06 \\
\hline 5 & $600-608$ & $6.23-6.29$ & $11.9-14.6$ & 0.085 \\
\hline 6 & $598-613$ & $6.19-6.27$ & $11-15.3$ & 0.06 \\
\hline 7 & $586-616$ & $6.11-6.27$ & $11.8-17.3$ & 0.09 \\
\hline 8 & 599-606 & $6.10-6.22$ & $11.0-13.7$ & 0.045 \\
\hline 9 & $586-608$ & $6.10-6.24$ & $11.2-15.0$ & 0.058 \\
\hline
\end{tabular}

had significant impact on the amount of drug dissolved from the tablet at $20 \mathrm{~h}$.

\section{Characterization of Granules}

Tablets were formulated by direct compression method and physicochemical properties of the granules were evaluated prior to compression. The granules of all the batches had shown good flow properties which is evident from the results depicted in Table 9. Bulk and tap density were used to calculate compressability index where bulk density ranged from 0.481 to 0.581 and tapped density ranged from 0.771 to 0.799 . The angle of repose value ranged from $25.09^{\circ}$ to $29.82^{\circ}$, as the angle of repose was found below $30^{\circ}$ it can be inferred that blend have good flow ability. The Hausner ratio ranged from 1.37 to 1.63. Form the reults it can be inferred that the granules posses free flowing property.

\section{Evaluation of Tablets}

Formulated tablets were evaluated for variation in weight, thickness, hardness and \% friability. The results obtained from these tests were found to be satisfactory which are depicted in Table 10. Results obtained from weight variation demonstrated that all the formulations

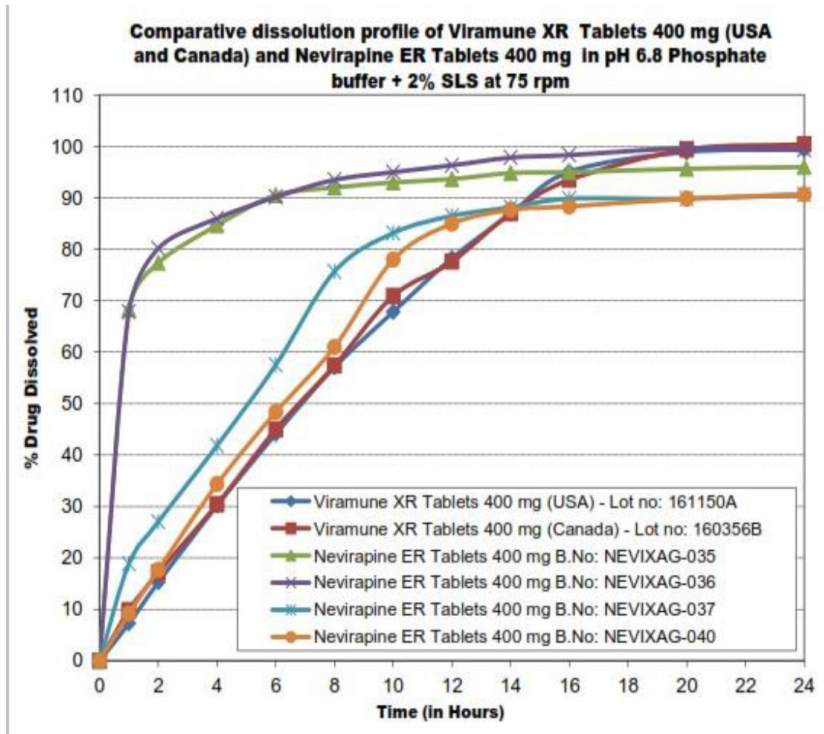

Figure 6: In vitro drug release in comparison with marketed products.

are within the limit of $7.5 \%$. Thickness of the tablets from all the batches was uniform and within the range of 6.09 to $6.30 \mathrm{~mm}$. Hardness of tablets of all batches ranged from 11 to $17.3 \mathrm{Kg} / \mathrm{cm}^{2}$. Friability of tablets from all batches ranged from 0.03 to 0.135 , which was well under limit.

\section{In vitro dissolution studies}

Dissolution studies for extended release of NVP were carried out in $900 \mathrm{ml}$ of $\mathrm{Ph}$. 6.8 phosphate buffer in USP Type- 2 dissolution apparatus at $75 \mathrm{rpm}$ and $37 \pm 0.5^{\circ} \mathrm{C}$ for $24 \mathrm{~h}$. Results demonstrated that concentration of polymer had shown a potential influence over drug release from tablets. Tablets with low polymer concentration exhibited a immediate release when compared with reference product. With increase in concentration of polymer release of Nevirapine was in a controlled manner when compared to reference product which is depicted in Figure 6.

\section{CONCLUSION}

The present research work foresees the applicability of QbD in formulating Nevirapine ER Tablets by using rate retarding polymers. From the results it was clearly evident that as the polymer concentration increases, there was a decline in the release of drug. Combination of polymers with other excipients do not interact with drug, which leads to sustained delivery of drug for longer periods. The optimized formulation from $2^{3}$ 2-Level factorial design can be used as a single dose per day in the management of HIV/AIDS. 


\section{ACKNOWLEDGEMENT}

The authors express their gratitude to the JSS University and JSS College of Pharmacy for providing necessary support in due course of the work.

\section{CONFLICT OF INTEREST}

The authors declare that there is no conflict of interest.

\section{ABBREVIATIONS}

Nevirapine: NVP; QbD: Quality by Design; DoE: Design of experimentatio; ICH: International Conference on Harmonisation; HIV/AIDS: Human immunodeficiency virus infection and acquired immune deficiency syndrome; NNRTI: Non-nucleoside reverse transcriptase inhibitor; RT: Reverse transcriptase; RNA: Ribonucleic acid; DNA: Deoxyribonucleic acid; ER: Extended Release; QTPP: Quality Target Product Profile; BE: Bioequivalent; CU: Content uniformity; CQA: Critical Quality Attribute; CMA: Critical material attributes; USP: United States Pharmacopeia; UV: Ultraviolet; ANOVA: Analysis of variance; PSD: Particle size diameter.

\section{REFERENCES}

1. Woodcock J. The concept of pharmaceutical quality. Am Pharmaceut Rev. 2004;7(6):10-5.

2. Q9: Quality Risk Management. ICH Harmonized Tripartite Guidelines. International Conference on Harmonization of Technical Requirements for Registration of Pharmaceuticals for Human Use. 2006.

3. Lionberger RA, Lee LS, Lee L, Raw A, Yu LX. Quality by design: Concepts for ANDAs. AAPS J. 2008;10(2):268-76.

4. Patel GM, Shelat PK, Lalwani AN. QbD based development of proliposome of lopinavir for improved oral bioavailability. Eur J Pharm Sci. 2017;108:50-61.
5. Tajiri S, Kanamaru T, Makoto K, Konno T, Nakagami H. Dosage form design and in vitro/in vivo evaluation of cevimeline extended-release tablet formulations. Int J Pharm. 2010;383(1-2):99-105.

6. Macha S, Yong CL, Darrington T, Davis MS, MacGregor TR, Castles M, et al. In vitro-in vivo correlation for Nevirapine extended release tablets. Biopharm Drug Dispos. 2009;30(9):542-50.

7. Saurí J, Zachariah M, Macovez R, Tamarit JL, Millán D, Suñé-Pou M, et al. Formulation and characterization of mucoadhesive controlled release matrix tablets of captopril. J Drug Deliv Sci Technol. 2017;42:215-26.

8. Dutta S, Sengupta M. Modified release dosage form and drug delivery. J Pharm Res. 2009;2(11):1728-9.

9. Marinho AT, Rodrigues PM, Caixas U, Antunes AM, Branco T, Harjivan $S G$, et al. Differences in nevirapine biotransformation as a factor for its sex-dependent dimorphic profile of adverse drug reactions. J Antimicrob Chemother. 2013;69(2):476-82.

10. Riska P, Lamson M, MacGregor T, Sabo J, Hattox S, Pav J, et al. Disposition and biotransformation of the antiretroviral drug nevirapine in humans. Drug Metab Dispos. 1999;27(8):895-901.

11. Patel P, Roy A, Vinod KSM, Kulkarni M. Formulation and evaluation of colon targeted tablets of ornidazole for the treatment of Amoebiosis. Int J Drug Dev and Res. 2011;3(1):52-61.

12. Manikandan M, Kannan K, Thirumurugu S, Manavalan R. Design and Evaluation of Amlodipine Besilate and Atorvastatin Calcium Tablets. Res J Pharm Biol Chem Sci. 2012;3(1):425-34.

13. Singh SK, Sharma V, Pathak K. Formulation and evaluation of taste masked rapid release tablets of sumatriptan succinate. Int $\mathrm{J}$ Pharm Pharm Sci. 2012;4(2):168-74.

14. Jadhav SB, Kaudewar DR, Kaminwar GS, Jadhav AB, Kshirsagar RV, Sakarkar DM. Formulation and evaluation of dispersible tablets of diltiazem hydrochloride. Int J Pharmtech Res. 2011;3(3):1314-21.

15. Metker V, Kumar A, Pathak N, Padhee K, Sahoo S. Formulation and evaluation of orodispersible tablets of lornoxicam. Int $\mathrm{J}$ Drug Dev Res. 2011;3(1):281-5.

16. Arya A, Sharma S, Kumar J, Chandra A, Jaiswal P. Formulation and evaluation of mouth dissolving tablets of ranitidine HCL. Int J Pharmtech Res. 2010;2(2):1574-7.

17. Anjankumar PB, Nazmuddin M, Kulkarni U, Hariprasanna RC. Formulation and evaluation of lornoxicam fast dissolving tablet. Int Res $\mathrm{J}$ Pharm. 2011;2(4):130-3.

\section{PICTORIAL ABSTRACT}

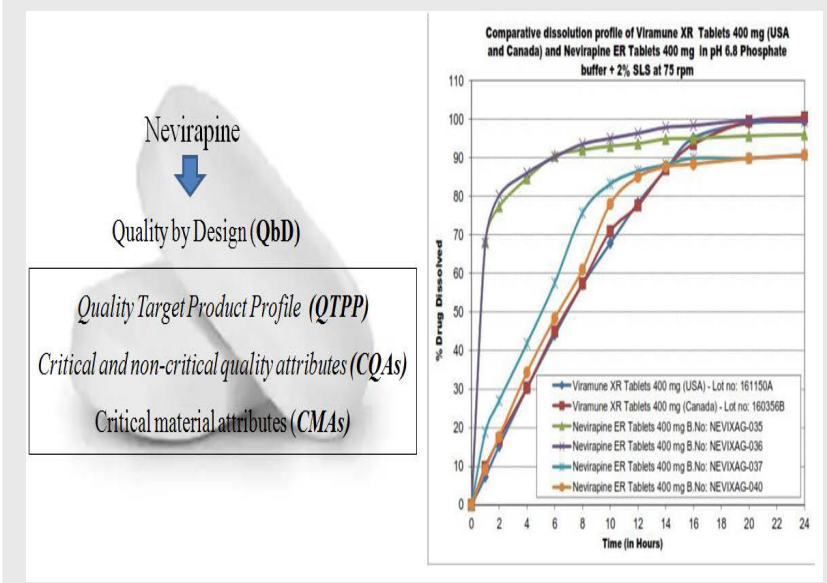

\section{SUMMARY}

- In the present study Nevirapine Extended release tablets were developed and evaluated using QbD approach.

- Methylcellulose USP Methocel A15-LV and Hypromellose USP Methocel K4M Premium CR were used as rate retarding polymers and Magnesium stearate was used as lubricant.

- From the obtained results it was inferred that concentration of polymer had shown a potential effect over various process parameters and in-vitro drug release studies suggested that formulated tablets had shown a sustained release up to $24 \mathrm{~h}$ when compared with marketed formulations 


\section{About Authors}

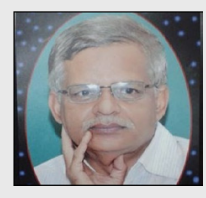

Dr. Vasantakumar Pai Karkala is working as a Professor in Department of Industrial Chemistry, Jana Sahyadri Campus at Shankaraghatta. His research area is chemistry and various novel drug delivery systems

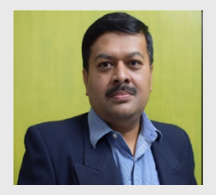

Mr. Harsha Jinadatharaya is working as a Research Scholar in Department of Industrial Chemistry, Jana Sahyadri Campus at Shankaraghatta. His research area is Tablets and Novel drug delivery systems.

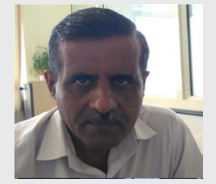

Dr. Devagowda Vishakante Gowda is working as Professor and Head for Department of Pharmaceutics at JSS College of Pharmacy, JSS Academy for Higher Education and Research, Mysuru. His research area is Tablets, Oral vaccines, Nano particles, Nasal delivery.

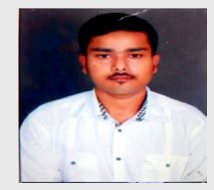

Mr Praveen Sivadasu is working as a Research Scholar at JSS College of Pharmacy, JSS Academy for Higher Education and Research, Mysuru. His research area is Nasal drug delivery

Cite this article: Karkala VP, Harsha J, Gowda DV, Praveen S. Development and Evaluation of Nevirapine Extended Release Tablets Using ObD Approach. Indian J of Pharmaceutical Education and Research. 2018;52(4 Suppl 2):s220-s228. 